\title{
Efektivitas Senam Otak dalam Meningkatkan Hafalan Al-Qur'an pada Siswa SMP-IT Ash-Shidiqi di Kecamatan Pemayung
}

\author{
Faridah $^{1}$, Ariyanto ${ }^{2}$ \\ ${ }^{1}$ Prodi D-III Fisioterapi, STIKes Baiturrahim Jambi \\ ${ }^{2}$ Prodi D-III Keperawatan, STIKes Baiturrahim Jambi \\ Email: taherfaridah821@gmail.com
}

Submitted : 30/04/2021

Accepted: 10/09/2021

Published: 15/09/2021

\begin{abstract}
Concentration of learning is an effort to focus the mind or attention to a subject that is being studied and to memorize the Al-quran by setting aside other things that have nothing to do with what is being studied. There are some students who are easy to accept the lessons / memorize alquran, and otherwise, there are several students too who have difficulty. Ash-Shidiqi Integrated Islamic Junior High School is a school that refers to the education office curriculum and the Indonesian Integrated Islamic School Curriculum with the flagship program Quantum Tahfizh, but in practice many students find it difficult to concentrate on memorizing Al-Qur'an. The results of interviews with students Ash-Shidiqi Integrated Islamic Junior High School, it is difficult to focus on their concentration in memorizing Al-qur'an because the school environment is not conductive, this is beside the according with the observations of researchers that many students are looking for a place to be alone in memorizing Al-qur 'an and sometimes students was found themselves to covering their heads with a bag to concentrate on memorizing. This type of research is quasi experimental (pseudo experiment). This study design had a control group, but it was not selected by randomly. In this study the researchers used two groups, namely the treatment group who were given brain exercise with a frequency of 6 times a week, light intensity, with duration of 1 exercise. The results showed that in the pre-test and post-test intervention groups there was $p=0.008$ or $p$ $<0.05$. It means that there are significant differences in the ability to memorize before and after being given brain exercise. Whereas in the control group $p=0.063$ or $p>0.05$ that means there is no significant difference between the pre-test and post-test results because they are not given brain exercise. This research is expected to make a good contribution to Ash-Shidiqi Integrated Islamic Junior High School in implementing the Quantum Tahfizh Program and will provide input in preparing the SMP-IT school program based on tahfizh al-quran.
\end{abstract}

Keywords: Al-Qur'an remembranc, brain gymnastics, effectiveness

\begin{abstract}
Abstrak
Konsentrasi belajar adalah suatu usaha pemusatan pikiran atau perhatian terhadap suatu mata pelajaran yang sedang dipelajari maupun kegiatan menghafal Al-qur'an dengan mengesampingkan hal-hal lain yang tidak ada hubungannya dengan apa yang sedang dipelajari. Ada beberapa siswa yang mudah dalam menerima pelajaran/ menghafal al-qur'an, namun ada juga siswa yang kesulitan. Sekolah Menengah Pertama Islam Terpadu (SMPIT) Ash-Shidiqi merupakan sekolah yang mengacu kurikulum Pendidikan Nasional dan Kurikulum Sekolah Islam Terpadu Indonesia dengan program unggulan Quantum Tahfizh, namun dalam pelaksanaannya banyak siswa yang susah untuk berkonsentrasi dalam menghafalkan al-qur'an. Hasil wawancara pada siswa -siswi SMPIT Ash-Sidiqi sulitnya untuk memfokuskan kosentrasi dalam menghafal Al-qur'an tersebut dikarenakan lingkungan sekolah yang tidak kondusif, hal ini sesuai dengan hasil pengamatan peneliti bahwa banyaknya siswa-siswa mencari tempat untuk menyendiri dalam menghafal Alqur'an dan terkadang ditemukan siswa/siswa menutup kepalanya dengan tas agar konsentrasi dalam menghafal. Penelitian ini diharapkan dapat memberikan kontribusi yang baik bagi SMP-IT Ash-Shidiqi dalam melaksanakan Program Quantum Tahfiz. Jenis penelitian ini quasi experimen (experimen semu). Desain penelitian ini mempunyai kelompok kontrol, tetapi tidak dipilih secara random. Pada penelitian ini peneliti menggunakan dua kelompok yaitu kelompok perlakuan yang diberi latihan senam otak dengan frekuensi 6 kali seminggu, intensitas ringan, durasi 1 kali latihan.
\end{abstract}


Hasil penelitian menunjukkan bahwa pada kelompok intervensi pre test dan post tes terdapat $\mathrm{p}=$ 0,008 atau $\mathrm{p}<0,05$. Berarti terdapat perbedaan siqnifikan kemampuan hafalan sebelum dan sesudah diberikan senam otak. Sedangkan pada kelompok kontrol $p=0,063$ atau $p>0,05$ berarti tidak terdapat perbedaan siqnifikan antara hasil pre tes dan post test karena tidak diberikannya senam otak.

Kata Kunci: efektivitas, hafalan al-qur'an, senam otak

\section{PENDAHULUAN}

Islamic Boarding School merupakan bentuk dari sekolah yang mana siswasiswinya bertempat tinggal di asrama. Dengan menanamkan nilai-nilai Islami Jadi, di zaman yang serba modern ini, Islamic Boarding School menjadi alternatif pendidikan yang menarik, terutama bagi insan-insan muda zaman sekarang.

Faktor- factor untuk meningkatkan prestasi belajar adalah dengan melakukan bimbingan belajar, konseling, sistem pembinaan guru, peningkatan motivasi, serta pelaksanaan hafalan Al-Qur'an . Hasil penelitian Heru Siswanto, dkk (2018) menyatakan ada hubungan antara menghafal Al-Qur;an dengan kecerdasan Siswa. Dengan pembiasaan menghafal AlQur'an maka diharapkan akan terjadi peningkatan hasil belajar siswa di sekolah melalui peningkatan prestasi belajar.

Menghafal Al-Qur'an masih sangat jarang dilakukan untuk usaha peningkatan prestasi belajar anak. Keistimewaan AlQur'an adalah mudah dihafal di luar kepala, mudah diingat, dan ayat-ayatnya terdapat harmoni, keselarasan dan kemudahan yang membuat ia mudah dihafal. Para ulama menyebutkan beberapa manfaat menghafal Al-Qur'an di antaranya adalah menajamkan ingatan dan mencemerlangkan pemikiran karena itu para penghafal Al-Qur'an lebih cepat mengerti dan teliti karena banyak berlatih untuk mencocokkan ayat serta membandingkan dengan ayat lain . Jika mendengarkan musik klasik dapat mempengaruhi kecerdasan intelektual (IQ) dan kecerdasan emosi (EQ) seseorang, bacaan Al-Qur'an lebih dari itu. Membaca Al-Qur'an dapat mempengaruhi kecerdasan spiritual (SQ)
Menurut Ayinosa (2009) jika seseorang mengalami kesulitan belajar maka orang tersebut akan berusaha sangat keras dalam belajar yang mengakibatkan terjadi stres di otak, sehingga mekanisme integrasi otak melemah dan bagian-bagian otak tertentu kurang berfungsi. Dengan memaksakan otak untuk bekerja sangat keras maka akan terjadi ketidakseimbangan dalam otak antara otak kanan dan otak kiri, juga dapat menyebabkan kelelahan pada otak sehingga konsentrasi dalam belajar anak menjadi menurun.

Salah satu cara untuk mengatasi stres belajar dapat dengan melaksanakan kegiatan yaitu gerakan sederhana yang dilaukan untuk merangsang kerja dan fungsi otak secara maksimal yang disebut dengan senam otak (Dikir et al., 2016)

Menghafal Al-Qur'an dibutuhkan pemusatan perhatian dan pikiran. Untuk itu dibutuhkan kosentrasi agat focus dalam menghafal al-qur'an. Konsentrasi adalah pemusatan perhatian pada topik atau materi yang sedang di pelajari untuk memperoleh pemahaman dan pengetahuan yang dapat di gunakan ketika di butuhkan (Pratiasi, W.D \& Yuwono, 2018)

Teori konsentrasi yang di kemukakan oleh (Idrus, 2018) menyatakan bahwa konsentrasi adalah memusatkan pikiran pada situasi dan kondisi dalam belajar. Konsentrasi merupakan salah satu cara untuk memusatkan perhatian pada obyek yang di pelajari.

Sekolah Menengah Pertama Islam Terpadu (SMPIT) Ash-Shidiqi berdiri tahun 2014 yang berlokasi di Kecamatan Pemayung. Kabupaten Batang Hari Provinsi Jambi merupakan sekolah yang mengacu kurikulum DIKNAS dan 
Kurikulum Sekolah Islam Terpadu Indonesia dengan program unggulan Quantum Tahfizh/ setoran hafalan 30 juz dalam tempo 3 bulan yang dikhususkan pada siswa/siswa kelas 7 . Dalam 3 tahun program quantum tahfizh ini hanya $15-20$ $\%$ siswa yang mampu menyetor hafalan 30 juz, selebihnya siswa hanya mampu menyetor hafalan 5 juz sampai 20 juz, hal ini dikarenakan latar belakang siswa yang berbeda-beda dan tidak semua siswa berasal dari SDIT yang memiliki kurikulum Sekolah Islam Terpadu, sehingga siswa yang berasal dai SD Negeri yang hanya menggunakan kurikulum Diknas tidak terbiasa dengan pola setoran tahfizh AlQur'an, namun disamping itu juga banyak siswa yang susah untuk berkonsentrasi dalam menghafalkan al-qur'an. Hasil wawancara pada siswa -siswi SMPIT AshSidiqi sulitnya untuk memfokuskan kosentrasi dalam menghafal Al-qur'an tersebut dikarenakan lingkungan sekolah yang tidak kondusif, hal ini sesuai dengan hasil pengamatan peneliti bahwa banyaknya siswa-siswa mencari tempat untuk menyendiri dalam menghafal Al-qur'an dan terkadang ditemukan siswa/siswa menutup kepalanya dengan tas agar konsentrasi dalam menghafal.

Hasil penelitian (Rizky, 2021)Ada pengaruh yang positif dan signifikan antara kemampuan menghafal Al-qur'an dengan konsentrasi.

Salah satu cara untuk meningkatkan keberhasilan pembelajaran yaitu dengan metode pembelajaran yang menyenangkan. agar dapat mengatifkan suasana rileks dan tercipta suasana yang kondusif. Pembelajaran yang menyenangkan (joyful learning) merupakan suatu proses pembelajaran yang di dalamnya terdapat sebuah kebersamaan yang kuat antara pendidik dan peserta didik, tanpa ada perasaan terpaksa atau tertekan, guru menciptakan suasana yang demokratis.(Saefuddin, A \& Berdiati, 2014)
Menurut (Ismail, 2011) pembelajaran menyenangkan yaitu ketika pembelajaran berlangsung siswa dapat merasakan suasana rileks yang menyenangkan berkesan dan siswa merasakan tidak ada ketegang baik fisik maupun non fisik. Suasana yang menyenangkan dalam proses pembelajaran diharapkan akan memberikan kenyamanan tersendiri bagi peserta didik dalam belajar, sehingga siswa dapat mendayagunakan seluruh potensi yang dimilikinya. Untuk menciptakan suasanya yang menyenangkan tersebut tentunya diperlukan suatu metode yang menyenangkan yang membuat anak rileks dalam belajar, misalnya metode belajar sambil bermain ataupun belajar langsung dengan alam sekitar. Akan tetapi perancangan program seperti itu tidak selalu akan berhasil, karena pada dasarnya hanyalah mengoptimalkan sebagian fungsi otak, yaitu belahan otak kiri padahal kegiatan belajar akan optimal jika kita dapat mengoptimalkan penggunaan semua dimensi otak.

Manusia di karunia oleh Allah SWT Otak yang dapat digunakan utuk berfikir sehinggan manusia berbeda dengan makhluk ciptaan Allah lainnya walaupun setiap manusia memiliki perbedaan dalam proses berfikitnya , ada yang berpikir cepat, ada yang berpikir sedang dan ada yang berpikir lambat semua ini tergantung manusianya mau berusaha atau tidak (Timotius, 2018)

Menurut Pinel dalam (Prima, 2019) berpendapat bahwa otak manusia memiliki empat bagian pada tiga tingkatan yang berbeda dari atas batang otak dan yang keempat terselip di bagian belakang, Otak manusia juga memiliki dua sisi yang setiap sisinya mengontrol fungsi yang berbeda dan memproses informasi dengan cara yang berbeda pula.

Otak manusia terbagi menjadi dua hemisfer yaitu hemisfer kiri dan kanan. Hemisfer adalah belahan otak yang dikenal dengan otak kiri dan kanan. Menurut Hannaford C (1997) dalam(Sularyo \& 
Handryastuti, 2016) Masing-masing hemisfer mempunyai spesifitasnya sendiri. Kedua hemisfer tersebut harus bekerja sama, teraktivasi, dan terintegrasi sepanjang waktu sehingga kita bisa mengakses semua informasi sensoris serta dapat berkomunikasi secara efektif, bergerak dan bereaksi terhadap informasi tersebut. untuk meningkatkan integrasi kedua hemisfer tersebut adalah dengan gerakan-gerakan fisik misalany senam otak, Tai Chi, Yoga, gimnastik, aerobik, berenang, ski, menyanyi , menari, bermain musik, dan lain-lain (Hannaford C dalam(Sularyo \& Handryastuti, 2016)

Senam otak pertama kali dikembangkan oleh Paul Dennison pada tahun 1969 untuk menolong anak-anak dan orang dewasa dengan kesulitan belajar. Sejak tahun 1987 penelitian mengenai senam otak ini telah dilakukan di seluruh dunia dengan hasil yang cukup bermakna

Hasil penelitian Zulaini, 2016 manfaat dari senam otak adalah meningkatkan konsentrasi, mengurangi stress, meningkatkan daya ingat, dapat berfikir lebih cepat, bagi pelajar dapat menangkap pelajaran dengan baik, dapat meningkatkan percaya diri, melawan penuaan dan meningkatkan rasa bahagia.

Tujuan dilakukan senam otak adalah untuk menangani yang sering kurang fokus terhadap sesuatu, serta tujuan bagi anak usia dini, senam ini sangat berguna untuk menambah kecerdasan, membuat kosentrasi anak terjaga, dan membuat anak semakin tanggap dan cerdas. Otak anak yang masih segar akan mampu menangkap gerakangerakan yang dilakukan saat senamotak dan secara tidak langsung otak anak akan bekerja sebagaimana mestinya (Putri, D.M.P \& Amalia, 2019)

Dalam Kamus Besar Bahasa Indonesia "Kosentrasi" adalah upaya pemusatan perhatian atau pikiran pada satu hal. Kosentrasi bisa juga dipahami sebagai pemusatan fungsi jiwa terhadap sesuatu masalah atau objek. Dalam belajar dibutuhkan kosentrasi dalam perwujudan perhatian terpusat. Pemusatan perhatian tertuju pada sesuatu objek terentu dengan mengabaikan masalah-masalah lain yang tak diperlukan.(Anggota IKAPI, 2002)
Menurut
(Djamarah,
2008)

konsentrasi (pemusatan perhatian) adalah pemusatan fungsi jiwa terhadap sesuatu masalah atau objek dengan mengosongkan pikiran dari hal-hal lain, yang dianggap menggangu. Jadi konsentrasi adalah memusatkan fungsi jiwa terhadap suatu objek yang diperhatikan siswa dan suatu pemusatan perhatian, pikiran dan perbuatan pada suatu objek yang sedang dipelajari dan mengabaikan segala hal yang tidak berkaitan dengan objek yang sedang dipelajari. Dalam suatu proses belajar konsentrasi itu merupakan salah satu faktor terpenting dalam mengikuti suatu proses pembelajaran supaya proses pembelajaran itu tercapai dan berhasil.

Brain gym (senam otak) menjadi suatu alat bantu pembelajaran yang sangat efektif. Brain gym bisa dilakukan untuk menyegarkan fisik dan pikiran siswa setelah menjalani proses pembelajaran yang membutuhkan konsentrasi tinggi yang mengakibatkan kelelahan pada otak. Walaupun sederhana, brain gym dapat mempermudah kegiatan belajar dan melakukan penyesuaian terhadap ketegangan, tantangan, dan tuntutan hidup sehari-hari. Banyak orang yang merasa terbantu dengan brain gym, seperti melepaskan stres, meningkatkan konsentrasi belajar menjernihkan pikiran, meningkatkan daya ingat, dan sebagainya.

Menurut (Bili \& Dewi, 2019)menyatakan bahwa ada perbedaan antara kosentrasi belajar kelompok intervensi (Senam otak) dengan kelompok kontrol . Hal senada dari penelitian (Dikir et al., 2016) bahwa ada pengaruh senam otak (brain gym) terhadap tingkat stres sebelum dan sesudah perlakuan yang diberikan dapat terbukti menurunkan tingkat stress karena senam otak merupakan aktivitas 
fisik yang dapat menghasilkan serotonin dan meningkatkan jumlah sel otak.

Serotonin adalah suatu transmitter monoamino yang isintesis pada neuroneuron serotonergis dalam system saraf pusat dan sel-sel enterokromafin dalam saluran pencernaan.

Serotonin mempengaruhi hampir semua aspek dalam kehidupan otak, seperti membentuk mood, melindungi sel otak dari proses penghancuran neuron dan meningkatkan memori. Selain menghasilkan serotonin, senam otak dapat meningkatkan jumlah sel otak pada hippocampus yaitu bagian otak yang mengatur memori dan proses belajar (Gamon dan Bragdon, 2005; Okta FS, 2010).

Menurut (Ghofur et al., 2020)Menghafal Alquran merupakan tindakan positif yang bakal diganjar pahala yang luar biasa dari Allah SWT. Di sisi lain, menghafal Alquran juga memiliki relevansi terhadap kecerdasan kognitif seseorang.

Menghafal Alquran dapat meningkatkan kemampuan mengingat karena dilakukan berulang-ulang untuk mengingat dan memahami setiap teks Ayat, Surah dan juz sesuai keaslian Alquran.

Hasil penelitian (Ariyanti Lidya, 2021) menyimpulkan terdapat peningkatan konsentrasi belajar pada anak setelah diberikan terapi s enam otak

Teknik kosentrasi efektif terjadi ketika mampu menikmati kegiatan yang sedang dilakukan dan mampu memfokuskan pikiran pada suatu objek yang dilakukan Untuk itu peneliti ingin mengetahui apakah Teknik senam otak efektif dalam Meningkatkan Hafalan AlQur'an pada siswa kelas 7 SMP-IT AshShidiqi Pemayung Muara Jambi.

\section{METODE PENELITIAN}

Jenis penelitian ini quasi experimen (experimen semu). Desain penelitian ini mempunyai kelompok kontrol, tetapi tidak dipilih secara random. Pada penelitian ini peneliti menggunakan dua kelompok yaitu kelompok perlakuan yang diberi latihan senam otak dengan frekuensi 6 kali seminggu, intensitas ringan, durasi 1 kali latihan).

\section{HASIL DAN PEMBAHASAN}

Penelitian ini tentang efektivitas Senam Otak dalam Meningkatkan Hafalan Al-Qur'an pada Siswa kelas 7 SMP-IT Ash-Shidiqi di Kecamatan Pemayung Kabupaten Batanghari Jambi yang telah dilaksanakan pada tanggal 2 Agustus s/d 31 Oktober 2017. Responden dalam penelitian ini adalah siswa kelas 7 yang berasal dari Sekolah Dasar Negeri (yang tidak mempunyai kurikulum tahfidz) dengan jumlah responden 10 responden dengan kelompok perlakuan dan 10 responden sebagai kelompok kontrol. Jenis peneilitain ini dirancang dalam bentuk Quasi Eksperimen Design dengan rancangan Non Equivalent Control Group. Penelitian ini dilakukan selama 3 bulan, dimana 1 minggu pertama dilakukan observasi pre test., pengenalan gerakan senam otak dan selanjutnya pada minggu kedua dimulai diberikannya intervensi senam otak setiap hari (kecuali hari minggu) pelaksanannya setelah zikir Al-mat'tsurat sekitar jam 05.30, jam 10 (setelah sholat dhuha), jam 4 (setelah sholat ashar) selama 10-15 menit

\section{Karakteristik Responden}

Berdasarkan hasil penelitian, maka didapatkan distribusi umur responden yang menunjukkan bahwa pada kelompok intervensi , distribusi responden berdasarkan umur adalah sebagian besar siswa berumur 12 tahun sebanyak.16 responden $(80 \%)$, siswa berumur 11 tahun sebanyak 4 ( $20 \%)$. Sedangkan distribusi umur responden yang pada kelompok kontrol , distribusi responden berdasarkan umur adalah sebagian besar siswa berumur 12 tahun sebanyak.15 responden ( $75 \%$ ), siswa berumur 11 tahun sebanyak 5 ( $25 \%$ )

Berdasarkan hasil penelitiam, maka didapatkan distribusi jenis kelamin responden yang menunjukkan bahwa pada kelompok intervensi, distribusi frekuensi responden berdasarkan jenis kelamin adalah 10 responden 
berjenis kelamin perempuan $(50 \%)$ dan responden laki-laki 10 responden ( $50 \%)$ Sedangkan pada kelompok kontrol, distribusi frekuensi respondenberdasarkan jenis kelamin adalah berjenis kelamin perempuan $10(50 \%)$ dan 10 responden berjenis kelamin laki-laki $(50 \%)$

Berdasarkan uraian diatas, dapat dilihat distribusi frekuensi karakteristik responden berdasarkan umur dan jenis kelamin pada tabel dibawah ini

Tabel 1.Distribusi Frekuensi karakteritik Responden pada Kelompok Intervensi

\begin{tabular}{lll}
\hline Karakteristik & $\mathrm{n}$ & $\%$ \\
\hline Umur & & \\
11 tahun & 5 & $25 \%$ \\
12 tahun & 15 & $75 \%$ \\
Jenis Kelamin & & \\
Perempuan & 10 & $50 \%$ \\
Laki-laki & 10 & $50 \%$ \\
\hline
\end{tabular}

Berdasarkan tabel 1 diatas bahwa dari 20 responden didapatkan bahwa sebagian besar usia responden yang berpartisipasi adalah usia 12 tahun sebanyak 15 (75\%) responden.dengan jenis kelamin laki-laki dan perempuan sebanyak $50 \%$

\begin{tabular}{lcc}
$\begin{array}{l}\text { Tabel 2. } \\
\text { karakteritik } \\
\text { Kontrol }\end{array}$ & $\begin{array}{c}\text { Distribusi } \\
\text { Responden }\end{array}$ & $\begin{array}{c}\text { Frekuensi } \\
\text { Kelompok }\end{array}$ \\
\hline & $\mathrm{n}$ & $\%$ \\
\hline Umur & & \\
11 tahun & 4 & $20 \%$ \\
12 tahun & 16 & $80 \%$ \\
$\begin{array}{l}\text { Jenis Kelamin } \\
\text { Perempuan }\end{array}$ & 10 & $50 \%$ \\
Laki-laki & 10 & $50 \%$ \\
\hline
\end{tabular}

Berdasarkan tabel 2 diatas bahwa dari 20 responden didapatkan bahwa sebagian besar usia responden yang berpartisipasi adalah usia 12 tahun sebanyak 16 (80\%) responden dengan jenis kelamin laki-laki dan perempuan sebanyak $50 \%$

Tabel 3. Distribusi Responden yang Tidak Senam Otak Berdasarkan Perolehan Hafalan

\begin{tabular}{ccc}
\hline Kategori & $\mathrm{n}$ & $\%$ \\
\hline Kurang & 7 & $35 \%$ \\
Sedang & 9 & $45 \%$ \\
Baik & 4 & $20 \%$ \\
\hline Total & 20 & $100 \%$ \\
\hline
\end{tabular}

Berdasarkan table 3. menunjukkan bahwa dari 20 responden yang tidak melakukan senam otak terdapat $7(35 \%)$ responden termasuk kategori hafalan kurang , $9(45 \%)$ responden kategori hafalan sedang dan 4 (20\%) responden kategori hafalan baik

Tabel 4. Distribusi Responden yang Mengikuti Senam Otak Berdasarkan Perolehan Hafalan

\begin{tabular}{ccc}
\hline Kategori & $\mathrm{n}$ & $\%$ \\
\hline Kurang & 2 & $10 \%$ \\
Sedang & 6 & $30 \%$ \\
Baik & 12 & $60 \%$ \\
\hline Total & 20 & $100 \%$ \\
\hline
\end{tabular}

Berdasarkan table 4. menunjukkan bahwa dari 20 responden yang mengikuti senam otak terdapat $2(10 \%)$ responden termasuk kategori hafalan kurang , 6 (30\%) responden kategori hafalan sedang dan 12 $(60 \%)$ responden kategori hafalan baik 
Tabel 5 Pengaruh Senam Otak terhadap Kemampuan Hafalan Al-qur'an

\begin{tabular}{lccccc}
\hline \multicolumn{2}{c}{ Kemampuan Hafalan } & & Min & Max & p value \\
\hline Kelompok & Pre tes & 0,28 & 0,0 & 1,10 & 0,008 \\
Intervensi & Post tes & 1,51 & & & \\
& & & 0,4 & 5,10 & \\
Kelompok & Pretes & 0,17 & 0,0 & 0,5 & 0,063 \\
Kontrol & Post tes & 0,27 & 0,10 & 1,0 & \\
\hline
\end{tabular}

Hasil Penelitian menjelaskan bahwa pada kelompok intervensi pre test dan post tes terdapat $\mathrm{p}=0,008$ atau $\mathrm{p}<0,05$. Berarti terdapat perbedaan siqnifikan kemampuan hafalan sebelum dan sesudah diberikan senam otak. Sedangkan pada kelompok kontrol $p=0,063$ atau $p>0,05$ berarti tidak terdapat perbedaan siqnifikan antara hasil pre tes dan post test karena tidak diberikannya senam otak. Berdasarkan uraian diatas dapat dilihat pengaruh senam otak terhadap kemampuan hafalan qur;an

\section{Karakteristik Responden}

Kisaran usia Sekolah Dasar berada di antara 6 atau 7 tahun sampai 12 tahun. Usia siswa pada kelompok kelas atas sekitar 9 atau 10 tahun sampai 12 tahun. Menurut Gunarsa dan Gunarsa (2017), secara kronologis, remaja adalah individu yang berusia antara 12 tahun sampai 22 tahun. Individu yang memasuki fase remaja memiliki peran dan tugas perkembangan baru pada tahap ini remaja sudah mampu memikirkan hal yang tidak terlihat atau peristiwa yang tidak dialami secara langusung (Gunarsa, S. D., \& Gunarsa, 2017)

Responden dalam penelitian ini memiliki umur 11-12 tahun dimana umur tersebut dasarnya perkembangan lebih menyukai bermain bergerak mberkelompok misalnya berolahraga atau aktivitas fisik lainnya terutama pada anak-laki-laki, begitu juga untuk anak perempuan sering juga memainkan permainan anak laki-laki, Usia 12-15 tahun dapat untuk meningkatkan ukuran tubuh, meningkatkan kemampuan fisik, menyempurnakan keterampilan gerak.
Caranya adalah dengan melakukan aktivitas fisik atau olahraga yang diprogram dengan baik dan teratur. Kegiatan olahraga perlu dilakukan agar dapat memberikan rangsangan untuk berkembang secara serasi, antara lain dengan melakukan kegiatan-kegiatan olahraga perorangan, berpasangan, beregu, olahraga untuk pembinaan kesegaran jasmani. Program latihan fisik perlu diberikan dengan memperhatikan perkembanganperkembangan fisiologis dan kesehatan (Husdarta, 2014).

\section{Pengaruh Senam Otak terhadap Kemampuan Hafalan Al-Qur'an}

Pelatihan senam otak yang dilakukan secara berturut-turut dan rutin dapat meningkatkan dampak positif yaitu meningkatkan kognitif siswa dalam proses belajar mengajar di sekolah (Dennison, 2006). Pelatihan senam otak dilakukan setelah zikir Al-mat'tsurat sekitar jam 05.30 WIB, jam 10.00 (setelah sholat dhuha), jam 16.00 WIB (setelah sholat ashar) selama 10-15 menit pagi hari sebelum siswa menerima pelajaran, hal ini dilakukan untuk membuat siswa menjadi lebih rileks, lebih fokus dalam menerima materi pembelajaran di kelas serta untuk membuka titik-titik positif belajar dan setoran hafalan ALQur'an . Pelatihan senam otak juga dilakukan setelah siswa menerima pembelajaran.

Pelatihan senam otak yang dilakukan secara berturut-turut dan rutin dapat meningkatkan dampak positif yaitu meningkatkan kognitif siswa dalam proses belajar mengajar disekolah (Dennison, 
2010). Pelatihan senam otak dilkakukan pagi hari sebelum siswa menerima pelajaran. Hal ini dilakukan untuk membatu siswa menjadi lebih rileks, lebih fokus dalam menerima pelajaran di kelas. Hal ini dikarenakan pembelajaran yang melelahkan atau menegangkan akan memutuhkan kosentrasi tinggi (Muhammad, 2010)

Keberhasilan suatu belajar dipengaruhi oleh kemampuan seseorang dalam memusatkan perhatiannya terhadap objek yang sedang dipelajarinya. Terkait hal tersebut, kosentrasi merupakan aspek yang penting bagi siswa dalam menghafal Alqur'an.

Kosentrasi merupakan keadaan pikiran atau asosiasi terkondisi yang diaktifkan oleh sensasi di dalam tubuh. Cara mengaktifkan sensasi di dalam tubuh adalah dengan membuat tubuh berada dalam keadaan yang rileks dan suasana yang menyenangkan, karena dalam keadaan yang tegang seseorang tidak akan dapat menggunakan otaknya dengan maksimal oleh karena pikiran menjadi kosong (Dennison, 2010). Lebih lanjut Prihastuti (2011) menegaskan bahwa suasana yang menyenangkan berarti siswa berada dalam keadaan yang sangat rileks dan tidak ada sama sekali keteganggan yang mengancam dirinya baik fisik maupun non fisik.Kosentrasi merupakan suatu keadaan pikiran yang diaktifkan oleh sensasi di dalam tubuh, untuk dapat mengaktifkan sensasi didalam tubuh dibuthkan untuk dapat mengaktifkan sensasi didalam tubuh dibutuhkan keadaan yang rileks dan suasana yang menyenangkan, karena seseorang dalam kondisi tegang maka otak tidak dapat digunakan secara maksimal. Seperti yang dikatakan Prihastuti (2012) bahwa suasana yang menyenangkan dalam hal ini berarti seseorang dlam keadaan sangat rileks, tidak ada sama sekali tegang yang mengancam dirinya baik secara fisik maupun non fisik.

Belajar akan menjadi sangat efektif apabila fungsi otak dapat bekerja secara optimal, apabila otak bekerja memlebihi batas maksimal dari fungsi yang seharusnya , maka akan terjadi ketidakseimbangan antara otak kanan dan otak kiri yang akan menyebabkan otak menjadi lelah sehingga kosentrasi dalam menghafal menjadi menurun. Oleh karena itu diperlukan suatu metode menyenagkan sebagai penunjang siswa untuk menghafal Al-qur'an agar lebih rileks. Salah satunya yaitu senam otak. Senam otak adalah serangkaian gerakan sederhana yang dilakukan untuk merangsang kerja dan fungsi otak secara maksimal. Senam otak berpotensi menstimulus daya tangkap seseorang terutama siswa Ash-Shidiqi yang mempunyai program Quantu Tahfidz disekolahnya.

Senam otak merupakan suatu gerakan yang memiliki banyak manfaat, antara lain: 1). Membantu peserta didik dalam mengikuti prosesbelajar mengajar secara berkesinambangan, aktif dan kreatif, 2). Memberikan stimulus terhadap aktivitas belajar peserta didik dengan menggunakan seluruh kemampuan otak, 3). Mengoptimalkan kegiatan belajar peserta didik, 4). Menjadikan peserta didik tidak mudah bosan dengan aktivitasnya, 5). Menumbukan rasa senang pada peserta didik, 6). Memungkinkan belajar tanpa stres, 7). Meningkatkan kepercayaan diri, 8). Memandirikan individu dalam hal belajardanmengaktifkan seluruh potensi dan keterampilan yang dimiliki oleh individu tersebut.

Menurut Dennison (2010), mekanisme kerja senam otak dibagi menjadi 3 dimenasi, yaitu: 1). Dimensi Lateralis. Dimensi ini berfungsi untuk merangsang otak kiri dan kanan. Dimensi ini juga bertujuan untuk mengoptimalkan kemampuan belajar siswa dan mampu menyerap kemampuan komunikasi yang lebih cepat, 2). Dimensi 
pemfokusan. Menurut Andri (2012), dimensi ini berfungsi untuk meringankan atau merelaksasi otak bagian belakang dan otak bagian depan, dan 3). Dimensi pemusatan. Kemampuan untuk menyeberangi garis pisah antara bagian atas dan bagian bawah tubuh dan mengkaitkan fungsi dari bagian tengah sistem limbis(midbrain) yang berhubungan dengan informasi emosional serta otak besar (cerebrum) untuk berpikirsejenak.(Dennison, 2010).

Gerakan senam otak akan mengaktifkan hubungan -hubungan syaraf antara tubuh dan otak sehingga memudahkan aliran energi elektromagnetis keseluruh tubuh. Menurut (Slameto., 2010) salah satu faktor yang dapat mempengaruhi kosentrasi adalah faktor fisik. Hal tersebut tentu dapat berkaitan dengan kondisi otak seseorang, maksudnya bahwa kondisi syaraf otak yang sehat dapat memicu timbulnya kosentrasi yang tinggi. Kondisi sistem syaraf juga adapat mempengaruhi kemampuan individu dalam menyeleksi sejumlah informasi dalam kegiatan perhatian.

Menurut. (Sukadiyanto., 2012) bahwa pemprosesan informasi yang berasal dari stimulus (rangsangan) sampai terjadi suatu respon Berupa gerak) akan mengalir menlalui batang otak yang disalurkan oleh sel syaraf didalam otak yang disebut dengan axon dan dendrit. Pada batang otak terdapat retucular formation yang merupakan suatu jaringan komunikasi neuron melalui axon dan dendrit yang kompleks . Apabila retucular formation akan teraktifasi dan muncullah kosentrasi. Retucular formation akan memiliki informasi yang relevan saja dan mampu menciptakan kesiagaan yang dapat menunjang kosentrasi (Dennison, 2010)

Kita telah mengetahui bahwa otak mengontrol semua fungsi tubuh, senam otak memanfaatkan dan membentuk relasi diantara otak dan tubuh, Dengan melakukan gerakan-gerakan untuk mengakses otak ternyata kita dapat mengintegrasikan semua area yang berhubungan dalam proses belajar sehingga kita dapat meningkatkan kemampuan untuk memaksimalkan kedua belah hemisfer dan memperbaiki penampilan. ( Carrigan C.dalam (Sularyo \& Handryastuti, 2016)

Senam otak membantu mengintegrasikan:Batang otak/ brain stem ( fungsi pernapasan, homeostasis dan tendon guardreflex) Otak tengah/mid brain (sistem limbik, kontrol suhu, memori, emosi, kelenjar dan kimia tubuh serta fight/flightresponse)Neo cortex (kemampuan berpikir yangtertinggi, komunikasi, hemisfer kiri dan kanan)Carrigan C.dalam (Sularyo \& Handryastuti, 2016)

Keberhasilan suatu proses belajar dipengaruhi oleh kemampuan seseorang dalam memusatkan perhatiannya terhadap objek yang sedang dipelajarinya. Terkait hal tersebut, konsentrasi merupakan aspek yang penting bagi siswa dalam mencapai keberhasilan proses belajar, atau dengan kata lain konsentrasi belajar memengaruhi prestasi akedemik (Dami \& Curniati, 2018)

Serotonin dikenal sebagai feel good chemical yang bertanggung jawab dalam menimbulkanrasanyaman-bahagiasehingga peningkatankadarserotonindiotakberperan dalam meningkatkan rasa nyaman danbahagia, menurunkan perasaan tertekan/ stres, serta memperbaiki mood. Selainitu, serotonin juga telah terbukti terlibat dalam proses belajar-mengingat pada level seluler baik secara langsung maupun tidak langsung. Diketahui bahwa jalur neuron serotonergik menginervasi berbagai daerah pada sistem saraf pusat, salah satu bagian yang padat diinervasi oleh neuron serotonergik adalah hipokampus yang merupakan bagian dari sistem limbik. Hipo kampus memegang peran penting dalam proses belajar dan memori serta kemampuan navigasi. Selain itu, beragam reseptor serotonin dapat ditemukan dihampir seluruh bagian otak. 
Hampir seluruh jenis reseptor serotonin juga dapat ditemukan melimpah pada hipokampus sehingga memungkinkan serotonin terlibat dalam berbagai mekanisme seluler dari proses belajar dan memori pada hipokampus bergantung pada jenis reseptor yangdiaktivasi,diantaranya depolarisasi dan eksitasi sel saraf postsinaptik, mekanisme fasilitasi sinaps, peningkatan penglepasan neurotrasnmiter lain (seperti asetilkolin, glutamat,GABA,dopamin), dan pembentukan neuron (neurogenesis) serta sinaps tambahan (sinaptogenesis).Olehkarenaitu, peningkatan kadar serotonin di otak yang diinduksi oleh latihan fisik, juga berimplikasi pada peningkatan kadar neurotransmiter ini pada hipokampus sehingga berkontribusi dalam meningkatkan fungsi dan struktur hipokampus. Peningkatan fungsi dan struktur hipo kampus ini berperan dalam meningkatkan kemampuan belajar dan memori, khususnya pembelajaran dan memori bergantung pada hipokampus (hippocampal-dependent

learningandmemory) (Carlson,2013;Young, 2007; Djavadian, 2004) dalam (Furqaani, 2017)

Hormon Endorphin dihasilkan saat tubuh kita berolahraga. Hormon Endorphin ini sering disebut hormon kebahagiaan, hal ini disebabkan karena hormon Endorphin mampu membuat seseorang menjadi bahagia. Hormon endorphin ini sering dianggap sebagai hormon kebahagiaan, hal ini disebabkan karena hormon endorphin mampu membuat seseorang merasa bahagia. Hidup yang bahagia mengindikasikan siswa telah mengalami kepuasan hidup; kepuasan terhadap kondisi yang dicita-citakan; kondisi luar yang biasa; perasaan bahagia; dan kepuasan terhadap hal-hal yang dianggap penting (Dami \& Curniati, 2018).

Endorphin akan dilepaskan saat tubuh manusia perlu meredakan rasa sakit, selama berolah raga, relaksasi dan selama melakukan aktivitas apa saja yang membangkitkan rasa nyaman, senang atau antusia ( Sugianto 2012, dalam Prasanti 2015). Oleh sebab itu hormon endoprin akan memberikan kenyamanan serta menjadikan tubuh lebih rileks ketika seseorang melakukan aktivitas gerak pada tubuh. Aktivitas gerak pada tubuh dapat terpicu ketika seseorang melakukan gerak senam otak , sehingga apabila siswa melakukan gerak senam otak secara rutin., hal ini mampu memicu keluarnya hormon endorphin. Hormon Endorphin dapat membuat siswa merasa lebih rileks dan tubuh lebih mudah untuk dikontrol dalam keadaan rileks, maka siswa akan lebih mudah untuk memfokuskan menghafal Alqur'an. Sehingga dapat dipahami bahwa dengan melakuan gerak senam otak dapat membantu mengaktifkan bagian bagian penting pada otak yang terkait dengan kosentrasi, seperti dapat mengaktikan dan menstimulus retucular formation yang mampu memilih informasi yang relevan saja, mampu menstimulus keluarnya hormon endorphin yang dapat membuat seseorang menjadi rileks dan mampu menghilangkan ketegangan pada syaraf-syaraf otot serta dapat mengaktifkan ketiga dimensi otak yaitu dimensi lateralis, pemfokusan dan pemusatan agar siswa mudah mengahafl Alqur'an . Dengan demikian, fungsi otak akan bekerja dengan optimal dan terciptanya kosentrasi menghafal

\section{SIMPULAN}

Kelompok intervensi pre test dan post tes terdapat $\mathrm{p}=0,008$ atau $\mathrm{p}<0,05$. Berarti terdapat perbedaan siqnifikan kemampuan hafalan sebelum dan sesudah diberikan senam otak. Sedangkan pada kelompok kontrol $p=0,063$ atau $p>0,05$ berarti tidak terdapat perbedaan siqnifikan antara hasil pre tes dan post test karena tidak diberikannya senam otak. 


\section{SARAN}

Adapun saran yang dapat peneliti berikan yaitu diharapkan Sekolah SMP-IT Ash-Shidiqi mendukung tentang program senam otak agar dapat membatu siswasiswi mengikuti program hafalan dengan suasana yang menyenangkan sehingga dapat meningkatkan kosentrasi siswa dalam menghafal A-Qur'an

\section{UCAPAN TERIMA KASIH}

Peneliti mengucapkan terima kasih kepada semua pihak yang sudah membantu dan terlibat di penelitian ini. Kepada Kepala SMPIT Ash-Shiqi, ustdzad dan ustadzah, serta siswa/siswi yang berpartisipasi dalam penelitia ini. Peneliti berharap penelitian ini menjadi rekomendasi penulis lain untuk membuat penelitian selanjutnya.

\section{DAFTAR PUSTAKA}

Anggota IKAPI. (2002). Rahasia Sukses Belajar 2002). Rineka Cipta.

Ariyanti Lidya, D. (2021). Penggunaan Terapi Senam Otak Pada Anak Dengan Masalah penurunan Kosentrasi Belajar di Desa Rawajitu Selatan. 4, 245-250.

Bili, L. D., \& Dewi, M. (2019). Efektivitas Senam Otak Dalam Meningkatkan Konsentrasi Belajar Siswa. Jurnal Penelitian dan Pengembangan Pendidikan, 2(2), 68-78. http://ejournal.upg45ntt.ac.id/index.ph $\mathrm{p} / \mathrm{ciencias} / \mathrm{index}$

Dami, Z. A., \& Curniati, S. (2018). Pola Asuh Autoritatif dan Jenis Kelamin sebagai Prediktor Big Five Personality Factors: Implikasinya Bagi Pelayanan Bimbingan dan Konseling. Jurnal Kajian Bimbingan dan Konseling, 3(4),182-196.

https://doi.org/10.17977/um001v3i420 $18 \mathrm{p} 182$

Dennison, P. E. (2010). Brain Gym. Grasindo.

Dikir, Y., Badi'ah, A., \& Fitriana, L. B.
(2016). Senam Otak (Brain Gym) Berpengaruh Terhadap Tingkat Stres pada Anak Usia Sekolah Kelas V di SD Negeri Pokoh 1 Wedomartani Ngemplak Sleman Yogyakarta. Jurnal Ners dan Kebidanan Indonesia, 4(2), 70.

https://doi.org/10.21927/jnki.2016.4(2) .70-74

Djamarah, S. (2008). Sukses Belajar. Rineka Cipta.

Furqaani, A. R. (2017). Latihan Fisik Sebagai Brain Booster Untuk Anak. Golden Age: Jurnal Pendidikan Anak Usia Dini, 1(1), 11-22. https://doi.org/10.29313/ga.v1i1.2688

Ghofur, A., Tinggi, S., Islam, A., \& Baihaqi, A. K. (2020).

Gunarsa, S. D., \& Gunarsa, S. (2017). Psikologi remaja. PT. BPK Gunung Mulia.

Husdarta. (2014). Psikologi Olahraga. Alfabeta.

Idrus, E. (2018). Membongkar Psikologi Belajar Aplikatif.

Ismail, S. (2011). Strategi pembelajaran agama Islam berbasis PAIKEM (1 ed.).

Muhammad, A. (2010). Bila Otak Kanan dan Otal Kiri Seimbang. DIVA Press.

Pratiasi, W.D \& Yuwono, S. (2018). Psikologi Eksperimen Konsep, Teori dan Aplikasi.

Prima, E. (2019). Perbedaan Biologis dalam Pembelajaran dan Dampak dari Gerakan Fisik pada Otak Anak. 14(2), 245-270.

https://doi.org/10.24090/yinyang.v14i2 .2019.pp

Putri, D.M.P \& Amalia, R. . (2019). Terapi dan Komplementer Konsep dan Aplikasi Dalam Keperawatan. PT Pustaka Baru.

Rizky. (2021). Pengaruh Kemampuan Menghafal Al-Qur'an Terhadap Konsentrasi Belajar Siswa MI Muhammadiyah 6 Ponorogo. Universitas Muhammadiyah 
Ponorogo.

Saefuddin, A \& Berdiati, I. (2014). Pembelajaran efektif.

Slameto. (2010). Belajar dan Faktor-faktor yang Mempengaruhinya. Rineka Cipta.

Sukadiyanto. (2012). Pengantar Teori dan Metodologi Melatih Fisik. Lubuk Agung.

Sularyo, T. S., \& Handryastuti, S. (2016). Senam Otak. Sari Pediatri, 4(1), 36. https://doi.org/10.14238/sp4.1.2002.36 $-44$

Timotius. (2018). Otak \& perilaku (A. Aditya (ed.)). Andi. 